\title{
Type of dietary lipids and storing time on egg stability
}

\author{
Tipo de lipídios da dieta e tempo de estocagem na estabilidade de ovos
}

\author{
Ana Lúcia Fernandes PEREIRA ${ }^{1 *}$, Tatiana Fontoura VIDAL², Virgínia Kelly Gonçalves ABREU ${ }^{1}$, \\ Jorge Fernando Fuentes ZAPATA², Ednardo Rodrigues FREITAS ${ }^{2}$
}

\begin{abstract}
The objective of this work was to evaluate the influence of diets containing different lipid sources on eggs quality during refrigerated storage, on yolk fatty acid composition, and on cholesterol in the yolk. Four diets were used containing Soy Oil (SO), Sunflower Seed (SS), and Meat and Bone Meal + Soy Oil $(\mathrm{MBM}+\mathrm{SO})$ or Meat and Bone Meal + Tallow $(\mathrm{MBM}+\mathrm{TA})$. The experiment followed a factorial design $4 \times 3$ with four dietary treatments and three storage times. The eggs were stored at $4{ }^{\circ} \mathrm{C}$ for 0,30 , and 60 days. The collected eggs were analyzed for egg weight loss, Haugh units, yolk moisture, yolk lipid oxidation, and cooked yolk firmness. Refrigerated storage reduced Haugh units, and increased yolk moisture. Sixty days of storage time reduced the firmness of hard-cooked yolk. There was an interaction between dietary treatment and storage time for egg weight loss and lipid oxidation. With regard to yolk fatty acid profile, MBM + TA diet increased the contents of palmitic and palmitoleic acids. The levels of oleic and arachidonic acids were higher in yolks from birds fed with SS diet. Linoleic acid level was higher in the yolk from treatment with SO diet. Diets containing MBM + SO induced higher levels of docosahexaenoic acid. Yolk cholesterol content was reduced with the inclusion of SS in the diet. Therefore, the type of lipid present in the diet and refrigerated storage for 60 days at $4{ }^{\circ} \mathrm{C}$ can affect the egg quality.

Keywords: eggs; soy oil; meat and bone meal; tallow; sunflower seed; lipid oxidation.
\end{abstract}

\section{Resumo}

O objetivo deste trabalho foi avaliar a influência de rações contendo diferentes tipos de lipídios sobre a qualidade de ovos durante a estocagem sob refrigeração e sobre a composição de ácidos graxos e colesterol da gema. Foram utilizadas quatro rações contendo Óleo de Soja (OS), semente de girassol (SS), Farinha de Carne e Ossos + Óleo de Soja (FCO + OS) ou Farinha de Carne e Ossos + Sebo Bovino (FCO + SB). Seguiu-se desenho fatorial $4 \times 3$, com quatro tipos de rações e três tempos de estocagem. Os ovos foram estocados a $4{ }^{\circ} \mathrm{C}$ por 0 , 30 e 60 dias. Os ovos coletados foram analisados para perdas de peso, unidades Haugh, umidade e oxidação lipídica da gema, e firmeza da gema cozida. A estocagem reduziu as unidades Haugh e aumentou a umidade da gema. Com 60 dias de estocagem houve uma redução da firmeza da gema cozida. Foi observada uma interação entre o tipo de ração e o tempo de estocagem para perdas de peso e oxidação lipídica. Quanto ao perfil de ácidos graxos, as dietas contendo $\mathrm{FCO}+\mathrm{SB}$ promoveram aumento nos níveis de ácidos palmítico e palmitoleico. Os níveis dos ácidos oleico e araquidônico foram maiores nas gemas das aves alimentadas com SG. Os níveis de ácido linoleico foram maiores no tratamento contendo OS na dieta. Dietas contendo FCO + OS induziram maiores níveis de ácido docosaexaenoico. O conteúdo de colesterol das gemas foi reduzido com a inclusão de SG na dieta. Portanto, o tipo de lipídio presente na ração e a estocagem sob refrigeração podem afetar a qualidade do ovo. Palavras-chave: ovos; óleo de soja; farinha de carne e ossos; sebo bovino; semente de girassol; oxidação lipídica.

\section{Introduction}

Chicken eggs are well established as an excellent source of all essential nutrients for persons of all ages. However, egg fatty acid composition has been associated with human health problems. Many people have been limiting their egg consumption because they associate high cholesterol content in this food with cardiovascular diseases (MELUZZI et al., 2000; KIM et al., 2004)

The fatty acid profile of the egg yolk is clearly affected by the fatty acid composition of hen diets, particularly its polyunsaturated acids content. Therefore, the use of nutritional strategies to improve the quality and composition of animal products constitutes a link among animal production, food technology, and human nutrition (AYERZA; COATES, 2001; SZYMOZYK; PISULEWISKI, 2003).
Considering the influence of the diet lipids on egg composition and the biological properties of this food, it could be thought that layer diets should be based exclusively on the use of unsaturated fatty acids. However, it is important to verify the relationship among types of acids because the highly unsaturated fatty acids increase egg susceptibility to lipid oxidation (GALOBART et al., 2002).

Several studies have investigated the effect of oils and fats such as sunflower, canola, and soybean oils, and tallow and lard on animal feeding (LATOUR et al., 1998; BAUCELLS et al., 2000). Moreover, meat and bone meal, which is a by-product of industrial processing of animal tissues, has high biological value protein and minerals, and it has been used as an alternative

1 Universidade Federal do Maranhão-UFMA, Rua Urbano Santos, S/N, CEP 65900-410, Imperatriz, Maranhão, Brazil, e-mail: anafernandesp@yahoo.com.br ${ }^{2}$ Departamento de Tecnologia de Alimentos, Universidade Federal do Ceará - UFC, Av. Mr. Hull, 2977, CEP 60356-001, Fortaleza, CE, Brazil 
source of protein and energy in animal feeding (PRICE; SCHWEIGERT, 1994).

The major causes for changes in egg quality during storage depend upon several factors such as microorganisms, initial quality of fresh eggs, temperature of storage, passage of undesirable odors and flavors into the egg, loss of water from the egg, and the $\mathrm{pH}$ of the egg content. During storage, egg deterioration occurs faster at high temperatures $(30$ to $\left.40{ }^{\circ} \mathrm{C}\right)$ than at refrigerated temperatures $\left(0\right.$ to $\left.4{ }^{\circ} \mathrm{C}\right)$ (CHAKRABORTY et al., 2005).

According to Silversides and Scott (2001), the albumen characteristics are used to assess the egg quality during storage, but the measurement of Haugh units is the most used method. Jones and Musgrove (2005) stored eggs at $4{ }^{\circ} \mathrm{C}$ for 70 days and registered a value of 67.43 Haugh units at the end of the storage indicating that eggs had still satisfactory quality.

To Ahn et al. (1999), birds fed diets containing conjugated linoleic acid provided rubbery and elastic yolks when cooked. Such changes were related to changes in the permeability of the vitelline membrane during the storage of eggs at $4{ }^{\circ} \mathrm{C}$.

Yolk lipid oxidation can occur during egg storage. This oxidation is an important deterioration that occurs in foods affecting its quality, especially flavor and nutritional value, and it may produce toxic compounds. Molecules more susceptible to oxidation are fatty acids, particularly the unsaturated ones (FENNEMA, 2000).

Thus, the objectives of the study were to determine the effects of layer diets containing different lipid sources on egg weight loss, Haugh units, yolk moisture, and lipid oxidation, as well as on the firmness of the hard-cooked egg yolk during refrigerated storage and on fatty acid composition and cholesterol in egg yolk.

\section{Materials and methods}

\subsection{Birds and diets}

The experiment was conducted at the Universidade Federal do Ceará, in the departments of Zootecnia and Tecnologia de Alimentos. 120 Dekalb Brown laying hens with 27 weeks of age were randomly distributed into 4 treatments with 5 replicates of 6 birds each. The diets were based on corn and soybean meal as main ingredients and formulated according to bird requirements as recommended by Rostagno et al. (2005). The diets contained either $2.40 \%$ Soybean Oil (SO), 5.00\% Meat and Bone Meal + 1.34\% Soybean Oil (MBM + SO), $5.00 \%$ Meat and Bone Meal $+1.68 \%$ Tallow $(\mathrm{MBM}+\mathrm{TA})$, or $9.00 \%$ Sunflower Seed (SS) as sources of energy.

The ingredient composition and the fatty acid profile of the experimental diets are shown in Tables 1 and 2, respectively.

The study was conducted for a feeding period for 84 days consisting of 4 periods of 21 days each. The birds were maintained in cages ( 1 pair per cage) with water and feed provided ad libitum.
Table 1. Composition of experimental diets containing $2.40 \%$ Soybean Oil (SO), 5.00\% Meat and Bone Meal $+1.34 \%$ Soybean Oil $(\mathrm{MBM}+\mathrm{SO}), 5.00 \%$ Meat and Bone Meal $+1.68 \%$ Tallow $(\mathrm{MBM}+\mathrm{TA})$, or $9.00 \%$ Sunflower Seed (SS).

\begin{tabular}{|c|c|c|c|c|}
\hline \multirow[t]{2}{*}{ Ingredients } & \multicolumn{4}{|c|}{ Experimental diets } \\
\hline & SO & $\mathrm{MBM}+\mathrm{SO}$ & $\mathrm{MBM}+\mathrm{TA}$ & SS \\
\hline Corn & 58.13 & 62.28 & 62.00 & 56.56 \\
\hline Soybean meal & 28.25 & 22.06 & 22.00 & 23.00 \\
\hline Meat and bone meal 50\% & 0.00 & 5.00 & 5.00 & 0.00 \\
\hline Soybean oil & 2.40 & 1.34 & 0.00 & 0.00 \\
\hline Tallow & 0.00 & 0.00 & 1.68 & 0.00 \\
\hline Sunflower seed & 0.00 & 0.00 & 0.00 & 9.00 \\
\hline Limestone & 8.71 & 8.11 & 8.11 & 8.73 \\
\hline Dicalcium phosphate & 1.75 & 0.48 & 0.48 & 1.78 \\
\hline Methionine & 0.15 & 0.14 & 0.14 & 0.15 \\
\hline Lysine & 0.00 & 0.04 & 0.04 & 0.16 \\
\hline Mineral premix ${ }^{1}$ & 0.05 & 0.05 & 0.05 & 0.05 \\
\hline Vitamin premix ${ }^{2}$ & 0.20 & 0.20 & 0.20 & 0.20 \\
\hline Salt & 0.36 & 0.30 & 0.30 & 0.37 \\
\hline Total & 100.00 & 100.00 & 100.00 & 100.00 \\
\hline \multicolumn{5}{|c|}{ Calculated composition } \\
\hline $\begin{array}{l}\text { Metabolizable energy } \\
\left(\mathrm{kca}^{\mathrm{kg}} \mathrm{kg}^{-1}\right)\end{array}$ & 2850.00 & 2850.00 & 2850.00 & 2850.00 \\
\hline Crude protein (\%) & 18.00 & 18.00 & 18.00 & 18.00 \\
\hline Calcium & 3.80 & 3.80 & 3.80 & 3.80 \\
\hline Avaliable phosphorus & 0.43 & 0.43 & 0.43 & 0.43 \\
\hline Sodium & 0.18 & 0.18 & 0.18 & 0.18 \\
\hline Lysine total & 0.93 & 0.93 & 0.93 & 0.93 \\
\hline Methionine total & 0.43 & 0.43 & 0.43 & 0.43 \\
\hline Methionine + cystine total & 0.72 & 0.72 & 0.72 & 0.72 \\
\hline Threonine & 0.65 & 0.65 & 0.65 & 0.65 \\
\hline Tryptophan & 0.20 & 0.20 & 0.20 & 0.20 \\
\hline
\end{tabular}

${ }^{1}$ Composition of mineral premix provided as follows per kilogram: $\mathrm{Cu}, 10 \mathrm{mg} ; \mathrm{Zn}, 50 \mathrm{mg}$; $\mathrm{Fe}, 40 \mathrm{mg}$; Mn, $65 \mathrm{mg}$; I, $1 \mathrm{mg}$; antioxidant $10.2 \mathrm{~g}$; coccidiostatic $1.02 \mathrm{~g}$; and selenium $0.15 \mathrm{mg} .{ }^{2}$ Composition of vitamin premix provided as follows per kilogram: vitamin A $7950 \mathrm{IU}$; vitamin $\mathrm{B}_{1} 1.95 \mathrm{mg}$; vitamin $\mathrm{B}_{12} 13.05 \mathrm{mcg}$; vitamin $\mathrm{B}_{2} 4.95 \mathrm{mg}$; vitamin $\mathrm{B}_{6}$ $3.30 \mathrm{mg}$; vitamin $\mathrm{D}_{3} 2200 \mathrm{IU}$; vitamin $\mathrm{E} 10.95 \mathrm{mg}$; vitamin $\mathrm{K}_{3} 1.80 \mathrm{mg}$; folic acid $0.81 \mathrm{mg}$; calcium panthothenate $12.0 \mathrm{mg}$; choline $0.51 \mathrm{~g}$; and niacin $36.0 \mathrm{mg}$.

Table 2. Fatty acid composition of experimental diets containing $2.40 \%$ Soybean Oil (SO), 5.00\% Meat and Bone Meal $+1.34 \%$ Soybean Oil $(\mathrm{MBM}+\mathrm{SO})$, and $5.00 \%$ Meat and Bone Meal $+1.68 \%$ Tallow $(\mathrm{MBM}+\mathrm{TA})$ or $9.00 \%$ Sunflower Seed (SS).

\begin{tabular}{lcccc}
\hline Fatty acid & \multicolumn{4}{c}{ Dietary treatments } \\
\cline { 2 - 5 }$(\%)$ & SO & MBM+SO & MBM+TA & SS \\
\hline C14:0 & Not detectable & Not detectable & 1.26 & Not detectable \\
C16:0 & 16.64 & 18.54 & 22.49 & 16.28 \\
C18:0 & 3.26 & 7.58 & 9.41 & 5.00 \\
C18:1n9c & 23.11 & 24.16 & 26.84 & 33.86 \\
C18:1n9t & Not detectable & Not detectable & 0.89 & Not detectable \\
C18:2n6 & 51.19 & 44.20 & 33.45 & 42.43 \\
a-C18:3n3 & 3.73 & 2.82 & 1.81 & 1.39 \\
\hline
\end{tabular}

At the third experimental period, four eggs from each replicate were collected to determinate lipid profile and cholesterol. Egg yolks were separated from white and were stored at $-20^{\circ} \mathrm{C}$ until analysis.

At the fourth experimental period (day 64), all eggs from each replicate were collected for three days. The eggs were placed in 
cardboard half cases and stored at $4{ }^{\circ} \mathrm{C}$ with $68 \%$ relative humidity until sampling time $(0,30$, and 60 days of storage). The collected eggs were identified and analyzed at each corresponding storage time, for egg weight loss, Haugh units, egg yolk moisture, egg yolk lipid oxidation, and cooked egg yolk firmness.

\subsection{Egg weight loss and Haugh units}

Collected eggs were individually weighed on day 0 and on days 30 and 60 during refrigerated storage. Egg weight loss was calculated by the difference between egg weight on the day of analysis and the egg weight on day 0 . Weight loss percentage was calculated in relation to day 0 egg weight.

Haugh units were calculated from the measurements of the albumen height and the egg weight using the following formula: $\mathrm{HU}=100 \times \log \left(\mathrm{H}+7.57-1.7 \times \mathrm{W}^{0.37}\right)$, where $\mathrm{HU}=$ Haugh unit; $\mathrm{H}=$ height of the albumen $(\mathrm{mm})$; and $\mathrm{W}=$ egg weight $(\mathrm{g})$.

\subsection{Moisture and lipid oxidation in egg yolk}

Moisture content of egg yolks was determined as described by Association... (1990). Lipid oxidation was measured by determining the thiobarbituric acid reactive substances (TBARS) in an acidic extract from egg yolk using the method described by Kang; Cherian and Sim (2001). The rose-pink color produced by the reaction between malondialdehyde (MDA) and 2-thiobarbituric acid was measured using a spectrophotometer (Biospectro, SP22, Curitiba, Brazil) at $531 \mathrm{~nm}$ wavelength. Lipid oxidation was expressed as TBARS numbers (mg.MDA. $\mathrm{kg}^{-1}$ sample).

\subsection{Firmness of hard-cooked egg yolks}

The firmness of egg yolks was determined according to the method described by Min et al. (2005). Sixteen grams of egg yolk were poured into a polypropylene cylindrical vessel $(2.5 \mathrm{~cm}$ diameter and $1.5 \mathrm{~cm}$ height $)$. The tubes were submerged in a water bath (Tecnal TE 057, Piracicaba, Brazil) at $100^{\circ} \mathrm{C}$ for 15 minutes. The samples were allowed to cool on ice for 30 minutes. Texture was measured using a Texture Analyzer (model TA-XT2i, Stable Micro System, Surrey) with a cylinder probe (38 $\mathrm{mm}$ diameter). The samples were compressed by cycles with $50 \%$ compression of the original height $(1.5 \mathrm{~cm})$ at $2.0 \mathrm{~mm} / \mathrm{s}$ crosshead speed. The tests were replicated three times on cooked yolks from different eggs, and the resistance was measured in Newtons (N).

\subsection{Fatty acid composition and cholesterol in egg yolk}

For diets and yolk fatty acid composition methyl esters were prepared by direct methylation, as described by Wang et al. (2000). Chromatographic analyses were performed using a gas chromatograph (VARIAN CP 3380, Walnut Creek, USA), equipped with a flame ionization detector and fused silica capillary column $(100 \mathrm{~m} \times 0.25 \mathrm{~mm}$ i.d. $)$. The carrier gas was hydrogen at a flow rate of $1.5 \mathrm{~mL} /$ minutes. The initial temperature of the column was set at $160{ }^{\circ} \mathrm{C}$; it was increased to $240{ }^{\circ} \mathrm{C}$ at a rate of $3.5^{\circ} \mathrm{C} /$ minute and then held at that temperature for an additional 10 minutes period. The detector and injection port temperatures were maintained at $250{ }^{\circ} \mathrm{C}$.
Injections of $1 \mu \mathrm{L}$ samples were performed at a split ratio of 10:1. Fatty acids were identified by comparison of their retention times with those of authenticated standard (Supelco 37 Component FAME Mix). The fatty acid methyl ester standard mixture contained 19 derivatives including saturated, monounsaturated, and polyunsaturated fatty acids with chain length from 4 to 24 carbon atoms. Fatty acid peak areas were quantified and expressed as percentage of total methyl esters.

Cholesterol was determined by direct saponification of egg yolk followed by gas chromatography analysis (same equipment described above) according to the method developed by Botsoglou et al. (1998). $1 \mu \mathrm{L}$ aliquots from the saponified extracts were injected (split-less mode) on a fused silica capillary column, $30 \mathrm{~m} \times 0.53 \mathrm{~mm}$ i.d., coated with SPB-1, and film thickness of $1.0 \mu \mathrm{m}$. The column temperature was programmed from 250 to $300{ }^{\circ} \mathrm{C}$ at $10{ }^{\circ} \mathrm{C} /$ minutes and held at $300{ }^{\circ} \mathrm{C}$ for 15 minutes. Injection port and flame ionization detector temperatures were set at $300^{\circ} \mathrm{C}$. Hydrogen carrier gas was set at $3.4 \mathrm{~mL} /$ minutes. All injections were performed in a splitless mode. The cholesterol was identified by comparing sample retention times to those of an authenticated standard. Quantification was carried out against an external standard from a curve plotted with cholesterol levels and peak area values. The cholesterol concentrations were expressed as mg.100 $\mathrm{g}^{-1}$ yolk.

\subsection{Statistical analysis}

The experiment followed a complete randomized factorial $(4 \times 3)$ design with four dietary treatments $(\mathrm{SO}, \mathrm{MBM}+\mathrm{SO}$, $\mathrm{MBM}+\mathrm{TA}$, and SS) and three storage times (0, 30, and 60 days).

The results were submitted to analysis of variance using the procedure PROC ANOVA (STATISTICAL..., 2000), and the Student-Newman-Keuls (SNK) test was used to compare mean values ( $5 \%$ of probability).

\section{Results and discussion}

There was no interaction $(\mathrm{p}>0.05)$ between dietary treatment and storage time for the values of Haugh units, yolk egg moisture, and cooked yolk firmness. However, an interaction $(\mathrm{p}<0.05)$ between dietary treatment and storage time was observed for egg weight loss and yolk lipid oxidation.

\subsection{Egg weight loss and Haugh units}

Egg weight loss increased ( $\mathrm{p}<0.05)$ with storage time in all treatments (Table 3). According to Caner (2005), weight loss during storage is mainly caused by evaporation of water and loss of $\mathrm{CO}_{2}$. Moreover, this reduction in egg weight with storage time may be due to the loss of ammonia, nitrogen, and hydrogen sulfide which are degradation products of the egg organic constituents (SILVERSIDES; BUDGELL, 2004).

Santos et al. (2009) reported an increase in the egg weight loss with storage for 21 days. These authors reported that the quality of eggs changes significantly according to the temperature and period of storage in terms of egg weight loss parameters. 
At day 0 , no significant difference $(p>0.05)$ in egg weight loss was observed among the four dietary treatments. After 30 days of storage, however, eggs from hens fed the SO diet had the highest $(\mathrm{p}<0.05)$ weight loss value, while those from hens fed the MBM + SO diet had the lowest $(\mathrm{p}<0.05)$ values. After 60 days of storage, eggs from hens fed the SO diet had higher $(\mathrm{p}<0.05)$ weight loss than those from hens fed the MBM + SO or MBM + TA diets (Table 3).

The eggshell cuticle has influence on the rate of water loss from eggs. Since the eggshell cuticle is composed largely of lipids, the type of fat in the hen diet may also modify the cuticle impact on egg water loss (PEEBLES et al., 1998). Therefore, the highest content of unsaturated fatty acids in the SO diet compared with the $\mathrm{MBM}+\mathrm{SO}$ and MBM + TA diets (Table 2) could have led to high weight loss due to a lower melting point of the fat in the eggshell cuticle.

There were no significant differences ( $p>0.05)$ among dietary treatments for egg quality measured as Haugh units (Table 4). These results are in agreement with those of Cachaldora et al. (2008), who did not observe significant changes in Haugh units evaluating the effects of the type and level of basal fat and the levels of dietary supplementation with fish oil on egg quality.

A reduction $(\mathrm{p}<0.05)$ in Haugh units with storage time was observed (Table 4). Jones and Musgrove (2005) also reported a reduction in Haugh unit values with storage time, when eggs were stored for 70 days at $4{ }^{\circ} \mathrm{C}$ and $80 \%$ relative humidity. Haugh unit reduction is supposed to be due to the decrease in thick albumen height. Multiple hypotheses for this phenomenon have been proposed including the breakdown of the ovomucin-lysozyme complex, decreasing carbohydrate content of ovomucin during storage, and increasing egg $\mathrm{pH}$ (HAMMERSHOJ et al., 2002; CHEN; THESMAR; KERR, 2005).
On the basis of Haugh unit values, the Department of Agriculture of the United States considers values larger than 72 , between 60 and 72, and below 60 for eggs with good, intermediate, and low quality, respectively (UNITED..., 2006). Caner (2005) classified egg quality grade as: grade A, Haugh units $>55$; B, $31<$ Haugh units $<54$; and $C$ Haugh units $<30$. According to the author, after 8 days of storage at room temperature the quality of a control egg sample shifted to B grade reaching $\mathrm{C}$ grade after 15 days.

According to these criteria for egg quality, the eggs analyzed in this study can be stored for 60 days at $4{ }^{\circ} \mathrm{C}$ since in this period the Haugh unit values were fairly higher those determined for fresh eggs of good quality. This result may be due to storage conditions; as reported by several studies, the storage temperature significantly influenced the Haugh unit values, and the eggs kept at lower temperatures showed higher Haugh unit values (ALLEONI; ANTUNES, 2001; XAVIER et al., 2008).

\subsection{Moisture and lipid oxidation of egg yolk}

There were no significant differences $(p>0.05)$ among treatments for yolk moisture (Table 5). Milinsk et al. (2003) did not observe significant changes in moisture yolk from hen fed with diets containing different sources of polyunsaturated fatty acids n-3 either.

Yolk moisture increased $(\mathrm{p}<0.05)$ with refrigerated $\left(4^{\circ} \mathrm{C}\right)$ storage for 60 days (Table 5). Ahn et al. (1999) also reported an increase in yolk moisture during a 49 -day storage at $4{ }^{\circ} \mathrm{C}$. According to these authors, during storage, water migrates from the albumen through of vitelline membrane to the yolk, and as a consequence the yolk water content increases. The excess water in the egg yolk determines the increase of its volume leading to the weakening of the vitelline membrane, which causes a flattening of the yolk when the egg is broken

Table 3. Egg weight loss from hens fed diets containing 2.40\% Soybean Oil (SO), 5.00\% Meat and Bone Meal + 1.34\% Soybean Oil (MBM + SO), $5.00 \%$ Meat and Bone Meal $+1.68 \%$ Tallow (MBM + TA), or $9.00 \%$ Sunflower Seed (SS) and stored for 60 days at $4{ }^{\circ} \mathrm{C}$ and $68 \%$ relative humidity.

\begin{tabular}{cccccc}
\hline $\begin{array}{c}\text { Storage time } \\
\text { (days) }\end{array}$ & SO & MBM+SO & MBM+TA & SS \\
\cline { 2 - 6 } & $0.00 \pm 0.00^{\mathrm{Ca}}$ & $0.00 \pm 0.00^{\mathrm{Ca}}$ & $0.00 \pm 0.00^{\mathrm{Ca}}$ & $0.00 \pm 0.00^{\mathrm{Ca}}$ & $0.00 \pm 0.00$ \\
$\mathbf{0}$ & $1.07 \pm 0.02^{\mathrm{Ba}}$ & $0.56 \pm 0.02^{\mathrm{Bc}}$ & $0.84 \pm 0.05^{\mathrm{Bb}}$ & $0.86 \pm 0.02^{\mathrm{Bb}}$ & $0.83 \pm 0.21$ \\
$\mathbf{3 0}$ & $1.72 \pm 0.02^{\mathrm{Aa}}$ & $1.55 \pm 0.02^{\mathrm{Ab}}$ & $1.55 \pm 0.02^{\mathrm{Ab}}$ & $1.65 \pm 0.60^{\mathrm{Aab}}$ & $1.62 \pm 0.08$ \\
$\mathbf{6 0}$ & $0.93 \pm 0.87$ & $0.70 \pm 0.78$ & $0.80 \pm 0.78$ & $0.84 \pm 0.83$ & - \\
\hline
\end{tabular}

$\mathrm{n}=5$. Means values with different capital letters within a column are significantly different $(\mathrm{p}<0.05)$ by SNK. Means values with different small letters within a row are significantly different $(\mathrm{p}<0.05)$ by SNK.

Table 4. Haugh units values in eggs from hens fed diets containing 2.40\% Soybean Oil (SO), 5.00\% Meat and Bone Meal + 1.34\% Soybean Oil $(\mathrm{MBM}+\mathrm{SO}), 5.00 \%$ Meat and Bone Meal $+1.68 \%$ Tallow $(\mathrm{MBM}+\mathrm{TA})$, or $9.00 \%$ Sunflower Seed (SS) stored for 60 days at $4{ }^{\circ} \mathrm{C}$ and $68 \%$ relative humidity.

\begin{tabular}{|c|c|c|c|c|c|}
\hline \multirow{2}{*}{$\begin{array}{l}\text { Storage time } \\
\text { (days) }\end{array}$} & \multicolumn{5}{|c|}{ Dietary treatments } \\
\hline & SO & $\mathrm{MBM}+\mathrm{SO}$ & MBM+TA & SS & Mean \\
\hline 0 & $83.13 \pm 4.66$ & $87.13 \pm 2.68$ & $83.69 \pm 2.94$ & $88.91 \pm 3.99$ & $85.72 \pm 2.77^{\mathrm{A}}$ \\
\hline 30 & $79.22 \pm 5.12$ & $78.95 \pm 4.76$ & $76.72 \pm 3.77$ & $80.46 \pm 4.49$ & $78.84 \pm 1.56^{\mathrm{B}}$ \\
\hline 60 & $70.92 \pm 4.51$ & $74.09 \pm 2.81$ & $71.77 \pm 5.44$ & $72.49 \pm 5.04$ & $72.32 \pm 1.34^{\mathrm{C}}$ \\
\hline Mean & $77.76 \pm 6.24^{\mathrm{a}}$ & $80.06 \pm 6.59^{\mathrm{a}}$ & $77.39 \pm 5.99^{\mathrm{a}}$ & $80.62 \pm 8.21^{\mathrm{a}}$ & - \\
\hline
\end{tabular}

$\mathrm{n}=5$. Means values with different capital letters within a column are significantly different $(\mathrm{p}<0.05)$ by SNK. Means values with different small letters within a row are significantly different $(\mathrm{p}<0.05)$ by SNK. 
on a flat surface (SCOTT; SILVERSIDES, 2000; SILVERSIDES; BUDGELL, 2004).

For all dietary treatments, yolk lipid oxidation increased $(\mathrm{p}<0.05)$ with storage time (Table 6). Franchini et al. (2002) also reported an increase in the TBARS values when the eggs were stored for 90 days at $4{ }^{\circ} \mathrm{C}$. In the present study, TBARS values oscillated between 0.47 and $1.40 \mathrm{mg}$.MDA. $\mathrm{kg}^{-1}$ yolk. These values were lower than those obtained by Lakins et al. (2009), when eggs were stored at $4{ }^{\circ} \mathrm{C}$ for 30 days.

At day 0 , yolks from hens fed the SO or the SS diets had the highest $(\mathrm{p}<0.05)$ TBARS values. After 30 and 60 days of storage, however, TBARS values were higher than those at day 0 only for the SO diet (Table 6).

The high TBARS values in the yolks from hens fed the SO diet can be due the incorporation of polyunsaturated fatty acids from this diet (Table 2). Polyunsaturated fatty acids are more prone to oxidation than saturated fatty acids (PAPPAS et al., 2005). Cherian et al. (2007) also reported high lipid oxidation in eggs from hen fed diets containing conjugated linoleic acid or fish oil, which contain polyunsaturated fatty acids.

The analysis of TBARS is an important food quality index indicating fat oxidation. In perfect quality products, TBARS values should be less than $3 \mathrm{mg}$ malonaldeyde/ $\mathrm{kg}$ (CADUN; CAKLI; KISLA, 2005). Therefore, the results reported in this study are bellow this limit showing that the eggs are adequate for consumption (Table 6).

\subsection{Firmness of hard-cooked egg yolk}

There were no significant differences $(\mathrm{p}>0.05)$ among dietary treatments for the firmness of hard-cooked yolks (Table 7). Shang et al. (2004) evaluated the effect of dietary conjugated linoleic acid in the firmness of hard-cooked yolk.
These authors did not observe differences on day 1 of storage in the yolks from hens fed conjugated linoleic acid and the yolks from control hens.

After 60 days of storage, lower ( $\mathrm{p}<0.05)$ firmness values in hard-cooked yolks were observed in comparison to 0 and 30 day storage times. This reduction in the firmness of hard-cooked egg yolk with storage might be due to the higher yolk moisture as a result of the migration of water from the albumen, through the vitelline membrane, to the yolk. This effect could make the cooked yolk more fluid (SCOTT; SILVERSIDES, 2000) and probably less firm.

\subsection{Fatty acid composition and cholesterol in the yolk lipids}

Except for the stearic acid (C18:0), most of the principal fatty acids in yolk lipids were significantly altered with the inclusion of SO, MBM + SO, MBM + TA, or SS in the diets (Table 8).

Palmitic acid $(\mathrm{C} 16: 0)$ content was different $(\mathrm{p}<0.05)$ in the yolk from all treatments with the lowest values for eggs from hens fed the SO diet and the highest values for those from the layers fed the MBM + TA diet. The content of this fatty acid in the yolk reflected its proportion in the diet since palmitic acid was higher in the diet with $\mathrm{MBM}+\mathrm{TA}$, followed by the $\mathrm{MBM}+\mathrm{SO}, \mathrm{SS}$, and SO diets.

Ferrini et al. (2008) also reported higher palmitic acid in abdominal fat of broiler chickens fed with TA than those fed sunflower oil.

Although the stearic acid contents (C18:0) in the different diets were significantly different (Table 2 ), there were no significant differences $(\mathrm{p}>0.05)$ in egg yolk contents (Table 8 ). These results suggest that the concentration of stearic acid in the yolk is not easily influenced by dietary manipulation.

Table 5. Yolk moisture in eggs from hens fed diets containing 2.40\% Soybean Oil (SO), 5.00\% Meat and Bone Meal + 1.34\% Soybean Oil (MBM + SO), $5.00 \%$ Meat and Bone Meal $+1.68 \%$ Tallow (MBM $+\mathrm{TA}$ ), or $9.00 \%$ Sunflower Seed (SS) stored for 60 days at the $4{ }^{\circ} \mathrm{C}$ and $68 \%$ relative humidity.

\begin{tabular}{cccccc}
\hline $\begin{array}{c}\text { Storage time } \\
\text { (days) }\end{array}$ & SO & MBM+SO & MBM+TA & SS & Mean \\
\cline { 2 - 6 } & $48.62 \pm 0.48$ & $48.80 \pm 0.48$ & $49.15 \pm 0.61$ & $49.31 \pm 0.88$ & $48.97 \pm 0.32^{\mathrm{C}}$ \\
$\mathbf{0}$ & $50.05 \pm 0.39$ & $50.61 \pm 0.58$ & $50.18 \pm 0.59$ & $50.35 \pm 0.50$ & $50.29 \pm 0.24^{\mathrm{B}}$ \\
$\mathbf{3 0}$ & $51.39 \pm 1.14$ & $50.85 \pm 0.87$ & $50.74 \pm 1.04$ & $51.07 \pm 1.56$ & $51.01 \pm 0.29^{\mathrm{A}}$ \\
$\mathbf{6 0}$ & $50.02 \pm 1.39^{\mathrm{a}}$ & $50.09 \pm 1.12^{\mathrm{a}}$ & $50.02 \pm 0.81^{\mathrm{a}}$ & $50.24 \pm 0.88^{\mathrm{a}}$ & - \\
Mean & & &
\end{tabular}

$\mathrm{n}=5$. Means values with different capital letters within a column are significantly different $(\mathrm{p}<0.05)$ by SNK. Means values with different small letters within a row are significantly different $(\mathrm{p}<0.05)$ by SNK.

Table 6. Thiobarbituric Acid-Reactive Substances (TBARS) values (mg.MDA. $\mathrm{Kg}^{-1}$ yolk) for egg yolks from hens fed diets containing $2.40 \%$ Soybean Oil (SO), 5.00\% Meat and Bone Meal + 1.34\% Soybean Oil (MBM + SO), 5.00\% Meat and Bone Meal + 1.68\% Tallow (MBM + TA), or 9.00\% Sunflower Seed (SS) stored for 60 days at the $4{ }^{\circ} \mathrm{C}$ and $68 \% \mathrm{RH}$ relative humidity.

\begin{tabular}{cccccc}
\hline $\begin{array}{c}\text { Storage time } \\
\text { (days) }\end{array}$ & SO & MBM+SO & MBM+TA & Dietary treatments & Mean \\
\cline { 2 - 6 } & $0.55 \pm 0.02^{\mathrm{Ca}}$ & $0.50 \pm 0.02^{\mathrm{Cb}}$ & $0.47 \pm 0.02^{\mathrm{Cc}}$ & $0.54 \pm 0.02^{\mathrm{Ca}}$ & $0.52 \pm 0.04$ \\
$\mathbf{0}$ & $1.06 \pm 0.10^{\mathrm{Ba}}$ & $0.60 \pm 0.02^{\mathrm{Bb}}$ & $0.57 \pm 0.02^{\mathrm{Bb}}$ & $0.63 \pm 0.02^{\mathrm{Bb}}$ & $0.71 \pm 0.23$ \\
$\mathbf{3 0}$ & $1.40 \pm 0.28^{\mathrm{Aa}}$ & $0.77 \pm 0.03^{\mathrm{Ab}}$ & $0.75 \pm 0.02^{\mathrm{Ab}}$ & $0.70 \pm 0.02^{\mathrm{Ab}}$ & $0.90 \pm 0.33$ \\
Mean & $1.00 \pm 0.43$ & $0.63 \pm 0.14$ & $0.60 \pm 0.14$ & $0.62 \pm 0.08$ & - \\
\hline
\end{tabular}

$\mathrm{n}=5$. Means values with different capital letters within a column are significantly different $(\mathrm{p}<0.05)$ by SNK. Means values with different small letters within a row are significantly different $(\mathrm{p}<0.05)$ by SNK. 
Table 7. Firmness (N) of cooked egg yolks from hens fed diets containing 2.40\% Soybean Oil (SO), 5.00\% Meat and Bone Meal $+1.34 \%$ Soybean Oil (MBM+SO), 5.00\% Meat and Bone Meal + 1.68\% Tallow (MBM+TA) or 9.00\% Sunflower Seed (SS), stored for 60 days at the $4{ }^{\circ} \mathrm{C}$ and $68 \%$ relative humidity.

\begin{tabular}{ccllll}
\hline \multirow{2}{*}{$\begin{array}{c}\text { Storage time } \\
\text { (days) }\end{array}$} & \multicolumn{5}{c}{ Dietary treatments } \\
\cline { 2 - 6 } & SO & MBM+SO & MBM+TA & SS & Mean \\
\hline 0 & $65.19 \pm 7.80$ & $58.38 \pm 8.54$ & $62.47 \pm 7.78$ & $62.77 \pm 10.16$ & $62.20 \pm 2.82^{\mathrm{A}}$ \\
30 & $73.61 \pm 7.89$ & $61.63 \pm 4.68$ & $65.78 \pm 6.21$ & $64.10 \pm 9.15$ & $66.28 \pm 5.18^{\mathrm{A}}$ \\
60 & $50.53 \pm 15.85$ & $52.91 \pm 9.35$ & $51.15 \pm 4.32$ & $45.97 \pm 4.54$ & $50.14 \pm 2.96^{\mathrm{B}}$ \\
Mean & $63.11 \pm 11.68^{\mathrm{a}}$ & $57.64 \pm 4.41^{\mathrm{a}}$ & $59.80 \pm 7.67^{\mathrm{a}}$ & $57.61 \pm 10.11^{\mathrm{a}}$ & - \\
\hline
\end{tabular}

$\mathrm{n}=5$. Means values with different capital letters within a column are significantly different $(\mathrm{p}<0.05)$ by SNK. Means values with different small letters within a row are significantly different $(\mathrm{p}<0.05)$ by SNK.

These results are in agreement with those of Latour et al. (1998), who did not observe significant changes in stearic acid of the yolks when the hens were fed with diets containing corn oil, lard, or poultry fat.

The amount of palmitoleic acid (C16:1) was higher $(\mathrm{p}<0.05)$ in yolks from hens fed the MBM + TA diet than those from the other treatments (Table 8). The increase in palmitoleic acid in the eggs could be due to the activity of the $\Delta-9$ desaturase enzyme, which catalyzes the insertion of a double bond between C9 and C10 atoms of palmitic acid (C16:0) during the formation of palmitoleic acid (AYDIN; COOK, 2004). Therefore, the higher palmitoleic content in the eggs from hens fed the MBM + TA diet followed those from hens fed MBM + SO diet and reflected the palmitic acid content in these diets, as shown in Table 2.

Cabrera et al. (2006) also observed higher palmitoleic acid in yolks from hens fed animal fat sources (TA and pressed-fat of bovine viscera) than those from hens fed vegetable sources (sunflower and rice oils).

Oleic acid $(\mathrm{C} 18: \ln 9 \mathrm{c})$ content was higher $(\mathrm{p}<0.05)$ in yolks from hens fed the SS diet (Table 8 ). The highest proportion of oleic acid in yolks from hens fed the SS diet supports the idea that the amount of fatty acid in the diet is directly responsible for its deposit in the yolk lipid fraction. The increase in the concentration of this acid could be a nutritional advantage for consumers due to its hypocholesterolemic effect (MAZALLI et al., 2004).

The linoleic acid $(\mathrm{C} 18: 2 \mathrm{n} 6)$ content was higher $(\mathrm{p}<0.05)$ in yolks from hens fed the SO diet than those from the others treatments (Table 8). The content of this fatty acid in the yolk also reflected its proportion in the diet. These results are in agreement with those of Pardío et al. (2005), who observed higher linoleic acid in yolks when the hens were fed diets rich in linoleic acid.

The arachidonic acid (C20:4n6) content was found to be higher $(\mathrm{p}<0.05)$ in yolks from hens fed the SS diet than those from the other treatments. Baucells et al. (2000) also reported increase in the proportion this of fatty acid in yolks from hens fed a sunflower oil diet.

According to Watkins (1991), at high dietary linoleic acid concentration, there is a process of elongation and desaturation of the carbon chain which coverts linoleic acid into arachidonic acid. Since the enzyme $\Delta-6$ desaturase also promotes the desaturation of linoleic acid into arachidonic acid and $a$-linolenic into docosohexaenoic and eicosapentaenoic
Table 8. Fatty acid composition and cholesterol of egg yolks from hens fed diets containing 2.40\% Soybean Oil (SO), 5.00\% Meat and Bone Meal + 1.34\% Soybean Oil (MBM + SO), 5.00\% Meat and Bone Meal $+1.68 \%$ Tallow (MBM + TA), or 9.00\% Sunflower Seed (SS).

\begin{tabular}{|c|c|c|c|c|}
\hline \multirow{2}{*}{$\begin{array}{c}\text { Fatty acid } \\
(\%)\end{array}$} & \multicolumn{4}{|c|}{ Dietary treatment } \\
\hline & SO & $\mathrm{MBM}+\mathrm{SO}$ & $\mathrm{MBM}+\mathrm{TA}$ & SS \\
\hline $\mathrm{C} 16: 0$ & $28.23^{\mathrm{d}}$ & $29.42^{\mathrm{b}}$ & $29.93^{a}$ & $28.88^{c}$ \\
\hline $\mathrm{C} 18: 0$ & $15.73^{\mathrm{a}}$ & $15.64^{\mathrm{a}}$ & $15.70^{\mathrm{a}}$ & $15.26^{\mathrm{a}}$ \\
\hline $\mathrm{C} 16: 1$ & $1.00^{\mathrm{c}}$ & $1.25^{\mathrm{b}}$ & $1.69^{\mathrm{a}}$ & $0.00^{\mathrm{d}}$ \\
\hline $\mathrm{C} 18: \ln 9 \mathrm{c}$ & $24.58^{\mathrm{c}}$ & $28.45^{\mathrm{b}}$ & $28.97^{\mathrm{b}}$ & $29.69^{\mathrm{a}}$ \\
\hline C18:2n6 & $20.03^{a}$ & $16.82^{\mathrm{c}}$ & $14.00^{\mathrm{d}}$ & $17.90^{\mathrm{b}}$ \\
\hline $\mathrm{C} 20: 4 \mathrm{n} 6$ & $5.16^{\mathrm{b}}$ & $4.81^{\mathrm{c}}$ & $4.75^{\mathrm{c}}$ & $5.76^{\mathrm{a}}$ \\
\hline $\mathrm{C} 22: 6 \mathrm{n} 3$ & $2.24^{\mathrm{a}}$ & $2.15^{\mathrm{a}}$ & $1.45^{\mathrm{b}}$ & $0.00^{c}$ \\
\hline \multicolumn{5}{|c|}{ Cholesterol (mg.100 g $\left.{ }^{-1}\right)$} \\
\hline & $729.85^{c}$ & $751.97^{\mathrm{b}}$ & $788.61^{a}$ & $636.10^{\mathrm{d}}$ \\
\hline
\end{tabular}

Means values with different letters within a row are significantly different $(\mathrm{p}<0.05)$ by SNK test, $\mathrm{n}=5$.

acids (DHA and EPA), there is competition for the formation of these products. Hence, an excess of linoleic acid may prevent the transformation of $\alpha$-linolenic into its derivates DHA and EPA. Therefore, the increase in arachidonic acid content in eggs from hens fed the SO or SS diets could be attributed to the high linoleic acid content in these diets (Table 2).

The content of DHA (C22:6n3) was found to be higher $(\mathrm{p}<0.05)$ in yolks from hens fed the SO or MBM + SO diets (Table 8). These results are in agreement with Grobas et al. (2001), who reported an increase in DHA content in the eggs from hens fed the diets containing SO.

The increase in the long-chain n-3, DHA, in the eggs could be due to desaturation and elongation of $\alpha$-linoleic acid in hen livers (CARRILLO-DOMÍNGUEZ et al., 2005). Therefore, the higher DHA content in the eggs of hens fed the $\mathrm{SO}$ or $\mathrm{MBM}+\mathrm{SO}$ diets can be attributed to high proportion of a-linoleic acid (C18:3n3) in these diets.

In addition, DHA is of special interest due to its importance in brain and retinal neonatal development (SIMOPOULOS, 2000). Considering that humans seem to have a limited ability to desaturate the last step of formation of DHA from $a$-linoleic acid, eggs can be considered an interesting dietary source of such fatty acid (BAUCELLS et al., 2000).

In this study, the fatty acid composition of yolk lipids (Table 5) reflected that of the laying hen diets (Table 2). These 
results are in agreement with those of Collins et al. (1997) and Mazalli et al. (2004), who reported that the fatty acid composition of yolk could be manipulated by dietary lipids.

The lowest $(\mathrm{p}<0.05)$ cholesterol content was found in yolks from hens fed the SS diet (Table 8). These results are in agreement with Mazalli et al. (2004), who reported a reduction of egg cholesterol content by using diets containing sunflower oil.

Concern regarding the content of cholesterol of the human diet has grown because of the probable importance of cholesterol and cholesterol oxide products in the development of atherosclerosis (KIM et al., 2004). The results obtained in the present experiment suggest that the use of SS in hen diets improve the nutritional value of egg by reducing its cholesterol content.

\section{Conclusions}

On the basis of these observations it can be concluded that:

Egg quality characteristics (Haugh units, yolk moisture, and hard-cooked yolk firmness) are not affected when hens are fed diets containing $2.4 \%$ soybean oil, $5 \%$ meat and bone meal $+1.34 \%$ soybean oil, $5.0 \%$ meat and bone meal $+1.68 \%$ tallow, or $9.0 \%$ sunflower seed;

The inclusion of soybean oil in the diet negatively affects egg quality by increasing egg weight loss and yolk lipid oxidation;

Storing eggs for 60 days at $4{ }^{\circ} \mathrm{C}$ and 68 relative humidity lead to moderate reduction in Haugh units and firmness of the hard-cooked yolk; in addition, it increases yolk moisture, egg weight loss, and yolk lipid oxidation;

The results also show that the diet containing $2.4 \%$ soybean oil provides the egg enrichment with polyunsaturated fatty acids, and the diet containing 9.0\% sunflower seed improves the nutritional value of the egg by reducing its cholesterol content.

\section{References}

AHN, D. U. et al. Effect of dietary conjugated linoleic acid on the quality characteristics of chicken eggs during refrigerated storage. Poultry Science, v. 78, n. 6, p. 922-928, 1999.

ALLEONI, A. C. C.; ANTUNES, A. J. Unidade Haugh como medida da qualidade de ovos de galinha armazenados sob refrigeração. Scientia Agricola, v. 58, n. 4, p. 681-685, 2001. http://dx.doi. org/10.1590/S0103-90162001000400005

ASSOCIATION OF OFFICIAL ANALYTICAL CHEMISTS AOAC. Fat in eggs: Acid hydrolysis method. 13. ed. Washington: AOAC, 1990. Official Methods of Analysis 925.32.

AYERZA, R.; COATES, W. Omega-3 enriched eggs: The influence of dietary a-linolenic acid fatty acid source on egg production and composition. Canadian Journal of Animal Science, v. 81, n. 3, p. 355-362, 2001. http://dx.doi.org/10.4141/A00-094

AYDIN, R.; COOK, M. E. The effect of dietary conjugated linoleic acid on egg yolk fatty acids and hatchability in Japanese quail. Poultry Science, v. 83, n. 12, p. 2016-2022, 2004. PMid:15615015.

BAUCELLS, M. D. et al. Incorporation of different polyunsaturated fatty acids into eggs. Poultry Science, v. 79, n. 1, p. 51-59, 2000. PMid:10685889.
BOTSOGLOU, N. A. et al. Yolk fatty acid composition and cholesterol conten in resnponse to level and form of dietary flaxseed. Journal of Agricultural and Food Chemistry, v. 46, n. 11, p. 4652-4656, 1998. http://dx.doi.org/10.1021/jf980586x

CABRERA, M. C. et al. Enriching the egg yolk in n-3 fatty acids by feeding hens with diets containing horse fat produced in Urugay. Food Chemistry, v. 98, n. 4, p. 767-773, 2006. http://dx.doi. org/10.1016/j.foodchem.2005.07.013

CACHALDORA, P. et al. Effect of type and level of fish oil supplementation on yolk fat composition and n-3 fatty acids deposition efficiency in laying hens. Animal Feed Science Technology, v. 141, n. 1-2, p. 104-114, 2008. http://dx.doi. org/10.1016/j.anifeedsci.2007.05.024

CADUN, A., CAKLI, S.; KISLA, D. A study of marination of deepwater pink shrimp (Parapenaeus longirostris, Lucas, 1846) and its shelf life. Food Chemistry, v. 90, n. 1-2, p. 53-59, 2005. http://dx.doi. org/10.1016/j.foodchem.2004.03.024

CANER, C. The effect of edible eggshell coatings on egg quality and consumer perception. Journal of the Science of Food and Agriculture, v. 85, n. 11, p. 1897-1902, 2005. http://dx.doi. org/10.1002/jsfa.2185

CARRILLO-DOMÍNGUEZ, S. et al. Cholesterol and n-3 and n-6 fatty acid content in eggs from laying hens fed with red crab meal (Pleuroncodes planipes). Poultry Science, v. 84, n. 1, p. 167172, 2005. PMid:15685957.

CHAKRABORTY, A. et al. Effect of temperature and various egg shell treatments on quality of egg during storage. Indian Journal of Animal Health, v. 44, n. 1, p. 9-18, 2005.

CHEN, J.; THESMAR, H. S.; KERR, W. L. Outgrowth of Salmonellae and physical property of albumen and vitelline membrane as influenced by egg storage conditions. Journal of Food Protection, v. 68 , n. 12 , p. $2553-2558$, 2005. PMid:16355825.

CHERIAN, G. et al. Conjugated linoleic acid and fish oil in laying hen diets: effects on egg fatty acids, thiobarbituric acid reactive substances, and tocopherols during storage. Poultry Science, v. 86, n. 5, p. 953-958, 2007. PMid:17435031.

COLLINS, V. P. et al. Pearl millet in layer diets enhances egg yolk n-3 fatty acids. Poultry Science, v. 76, n. 2, p. 326-330, 1997. PMid:9057215.

FENNEMA, O. R. Química de los alimentos. 2. ed. Zaragoza: Editorial Acribia, 2000. 1258 p.

FRANCHINI, A. et al. Oxidative stability and sensory and functional properties of eggs from laying hens fed supranutritional doses of vitamins E and C. Poultry Science, v. 81, n. 11, p. 1744-1750, 2002. PMid:12455604.

FERRINI, G. et al. Dietary polyunsaturated fat reduces skin fat as well as abdominal fat in broiler chickens. Poultry Science, v. 87, n. 3, p. 528-535, 2008. PMid:18281580. http://dx.doi.org/10.3382/ ps.2007-00234

GALOBART, J. et al. Accumulation of $\alpha$-tocopherol in eggs enriched with $\omega 3$ and $\omega 6$ polyunsaturated fatty acids. Poultry Science, v. 81, n. 12, p. 1873-1876, 2002. PMid:12512580.

GROBAS, S. et al. Laying hen productivity as affected by energy, supplemental fat, and linoleic acid concentration of the diet. Poultry Science, v. 78, n. 11, p. 1542-1551, 1999. PMid:10560827.

JONES, D. R.; MUSGROVE, M. T. Effects of extended storage on egg quality factors. Poultry Science, v. 84, n. 11, p. 1774-1777, 2005. PMid:16463976.

HAMMERSHOJ, M. et al. Storage of shell eggs influences the albumen gelling properties. LWT - Food Science and Technology, v. 35, n. 1, p. $62-69,2002$. 
KANG, K. R.; CHERIAN, G.; SIM, J. S. Dietary palm oil alters the lipid stability of polyunsaturated fatty acid-modified poultry products. Poultry Science, v. 80, n. 2, p. 228-234, 2001. PMid:11233014.

KIM, J. H. et al. Oral administration of pravastatin reduces egg cholesterol but not plasma cholesterol in laying hens. Poultry Science, v. 83, n. 9, p. 1539-1543, 2004. PMid:15384905.

LAKINS, D. G. et al. Comparison of quality attributes of shell eggs subjected to directional microwave technology. Poultry Science, v. 88, n. 6, p. 1257-1265, 2009. PMid:19439638. http://dx.doi. org/10.3382/ps.2008-00273

LATOUR, M. A. et al. Broiler breeder age and dietary fat influence the fatty acid profiles of fresh eggs and newly hatched chicks. Poultry Science, v. 77, n. 1, p. 47-53, 1998. PMid:9469750.

MAZALLI, M. R. et al. A comparison of the feeding value of different sources of fat for laying hens: 2. Lipid, cholesterol, and vitamin $\mathrm{E}$ profiles of egg yolk. Journal Applied Poultry Research, v. 13, n. 2, p. 280-290, 2004.

MELUZZI, A. et al. Effects of dietary vitamin E on the quality of table eggs enriched with n-3 long-chain fatty acids. Poultry Science, v. 79, n. 4, p. 539-545, 2000. PMid:10780651.

MILINSK, M. C. et al. Fatty acid profile of egg yolk lipids from hens fed diets rich in n-3 fatty acids. Food Chemistry, v. 83, n. 2, p. 287 292, 2003. http://dx.doi.org/10.1016/S0308-8146(03)00094-3

MIN, B. R. et al. Effect of irradiating shell eggs on quality attributes and functional properties of yolk and white. Poultry Science, v. 84, n. 11, p. 1791-1796, 2005. PMid:16463979.

PAPPAS, A. C. et al. Effects of supplementing broiler breeder diets with organic selenium and polyunsaturated fatty acids on egg quality during storage. Poultry Science, v. 84, n. 8, p. 865-874, 2005.

PARDÍO, V. T. et al. The effect of soybean soapstock on the quality parameters and fatty acid composition of the hen egg yolk. Poultry Science, v. 84, n. 1, p. 148-157, 2005. PMid:15971522. PMid:15685955.

PEEBLES, E.D. et al. Effects of dietary fat and eggshell cuticle removal on egg water loss and embryo growth in broiler hatching eggs. Poultry Science, v. 77, n. 10, p. 1522-1530, 1998. PMid:9776060.

PRICE, J. F.; SCHWEIGERT, B. S. Ciencia de la carne y de los productos carnicos. Zaragoza: Editorial Acribia, 1994. 581 p.

ROSTAGNO, H. S. et al. Tablas Brasileñas para aves y cerdos Composicion de Alimentos y Requerimientos Nutriconales. 3. ed. Viçosa: UFV, 2005. 186 p.
SANTOS, M. S. V. et al. Efeito da temperatura e estocagem em ovos. Ciência e Tecnologia de Alimentos, v. 29, n. 3, p. 513-517, 2009. http://dx.doi.org/10.1590/S0101-20612009000300009

SCOTT, T. A.; SILVERSIDES, F. G. The effect of storage and strain of hen on egg quality. Poultry Science, v. 79, n. 12, p. 1725-1729, 2000. PMid:11194033.

SHANG, X.G.et al.Effect of dietary conjugated linoleicacid on productivity of laying hens and egg quality during refrigerated storage. Poultry Science, v.83, n.10, p.1688-1695, 2004. PMid:15510554

SILVERSIDES, F. G.; SCOTT, T. A. Effect of storage and layer age on quality of eggs from two lines of hens. Poultry Science, v. 80, n. 8, p. 1240-1245, 2001. PMid:11495479.

SILVERSIDES, F. G.; BUDGELL, K. The relationships among measures of egg albumen height, $\mathrm{pH}$, and whipping volume. Poultry Science, v. 83, n. 10, p. 1619-1623, 2004. PMid:15510543.

SIMOPOULOS, A. P. Role of poultry products in enriching the human diet with n-3 PUFA. Human requirement for n-3 polyunsatureted fatty acids. Poultry Science, v. 79, n. 7, p. 961-970, 2000. PMid:10901194.

STATISTICAL ANALYSIS SYSTEM INSTITUTE - SAS. SAS/STAT: User's guide. Version 6, 12. ed. Cary: SAS Institute Inc., 2000.

SZYMOZYK, B.; PISULEWSKI, P. M. Effects of dietary conjugated linoleic acid on fatty acid composition and cholesterol content of hen egg yolks. British Journal of Nutrition, v. 90, n. 1, p. 93-99, 2003. http://dx.doi.org/10.1079/BJN2003873

UNITED STATES DEPARTMENT OF AGRICULTURE - USDA. Egg grading manual. 2006. Disponível em: <http://www.ams.usda.gov/ poultry/pdfs/EggGrading\%20manual.pdf $>$. Acesso em: 30 jan. 2009.

WANG, Y. et al. Fatty acid determination in chicken egg yolk: a comparison of different methods. Poultry Science, v. 79, n. 8, p. $1168-1171,2000$.

WATKINS, B.A. Importance of essential fatty acids the irand derivatives in poultry. Journal of Nutrition, v.121, n.9, p.1475-1485, 1991. PMid:1880625. http://dx.doi.org/10.1021/jf026156v

XAVIER, I. M. C. et al. Qualidade de ovos de consumo submetidos a diferentes condições de armazenamento. Arquivo Brasileiro de Medicina Veterinária e Zootecnia, v. 60, n. 4, p. 953-959, 2008. http://dx.doi.org/10.1590/S0102-09352008000400026 